\title{
Pera Palace Hotel Construction Technology
}

\author{
Pera Palas Oteli Yapım Teknolojisi
}

\author{
Banu ÇELEBIOĞLU, @ Uzay YERGÜN
}

\section{ABSTRACT}

From the first quarter of the $18^{\text {th }}$ century, a new perspective for European civilization was adopted by the Ottoman Empire and this Westernization concept was transformed into an essential revolutionary movement in governmental and social structure. Therefore, the initials steps of implementing any change were taken with the decision of constructing the buildings with new functions that are required as the necessary structures of modern state and public, according to European architectural design models with modern building materials and construction technologies. Building materials fabricated by European industry, such as brick, steel and concrete, as well as construction technologies like brick arch, steel-frame and concrete were important determinants in the historical evolution of Ottoman architecture after the first quarter of the $19^{\text {th }}$ century. One of the first structures built with the new function and construction technology of Ottoman architecture is Pera Palace Hotel (1895) designed by famous architect of this period, Alexander Vallaury. Apart from the Ottoman palaces, it's a building that the first electricity is supplied, the first elevator is located and the first hot water is active. In this paper, the architectural characteristics of the first modern hotel structure built in the Pera region, the construction system vertically supported by prefabricated bricks and arched floor with steel beams will be carried out in the frame of the original architectural projects. The significance of the building will be revealed in terms of cultural values of the Ottoman architecture.

Keywords: $19^{\text {th }}$ century; arched floor system; Istanbul; Ottoman architecture; steel beam.

18. yüzyılın ilk çeyreğinden itibaren Osmanlı Devlet'inde Avrupa uygarlığına karşı bir açılım başlamış ve bu batılılaşma olgusu Tanzimat dönemiyle birlikte devlet ve toplum yapısındaki köklü bir modernleşme hareketine dönüşmüştür. Değişimin simgesel görüntüsünü ise İstanbul'a kazandırılmak istenen batılı bir başkent imajı oluşturmaktadır. Fakat ahşap yapılardan meydana gelen geleneksel kent dokusunun oluşturduğu çelişki, kentsel ve mimari yapıda köklü bir değişimi gerektirmiştir. Bu nedenle uygulamaya yönelik ilk adımlar Tanzimat reformları doğrultusunda çağdaş devlet ve toplum yapısının gereksinim duyduğu yönetim, eğitim, sağlık, ulaşım ve kamu düzenine ait yeni yapı türlerinin, Avrupa mimarlığının tasarım kalıplarının yanı sıra dönemin modern yapı malzemesi ve yapı üretim teknolojileri kullanılarak inşa edilmesine karar verilme-siyle atılmıştır. Avrupa endüstrisinin ürettiği fabrikasyon tuğla, çelik putrel ve beton gibi yapı malzemeleri ve bu malzemelerle şekillenen çelik iskelet, ciment-arme, fer-beton (ferro-concrete) ve betonarme iskelet gibi yapım teknolojileri, Osmanlı mimarlığının 19. yüzyılın ilk yıllarından sonraki tarihsel gelişim sürecinin şekillenmesine etken olmuştur. Osmanlı Imparatorluğu'nda yeni işlev ve yapım teknolojisiyle inşa edilmiş ilk yapılardan olan Pera Palas Oteli (1895) Levanten mimar Alexander Vallaury tarafından tasarlanmış, Osmanlı Sarayları'ndan sonra ilk kez asansörün kullanıldığı, elektriğin ve sıcak suyun sağlandığı yapı olmuştur. Bu makalede Pera bölgesinde inşa edilmiş ilk modern otel yapısının mimari özellikleri, dolu tuğla yığma duvarlar ve çelik iskelet sistemin birlikte kullanıldığı özgün yapım sistemi incelenecek, yapının tarihi ve kültürel değerleri irdelencektir.

Anahtar sözcükler: 19. yüzyıl; volta döşeme; Istanbul; Osmanlı mimarisi; çelik karkas.

\footnotetext{
Department of Restoration, Yıldız Technical University Faculty of Architecture, İstanbul, Turkey.

Article arrival date: June 17, 2018 - Accepted for publication: November 07, 2018

Correspondence: Banu ÇELEBIOĞLU. e-mail: banu.celebioglu@gmail.com

๑ 2019 Yıldız Teknik Üniversitesi Mimarlık Fakültesi - @ 2019 Yıldız Technical University, Faculty of Architecture
} 


\section{Introduction}

Throughout history, Istanbul has always been the most important city in Turkey in terms of industry, trade and service sectors and a prominent venue of culture and art. With its historical heritage and its natural beauties that constitute its cultural heritage and the extensive accommodation options, Istanbul is also a significant tourism center.

The first modern hotels of Turkey were built in the midst of $19^{\text {th }}$ century, at the opposite coast of Historical Peninsula, in the districts of Galata and Pera, located east of the Golden Horn. Reforms made following the edict of Gülhane in 1839 have started the intense Westernization period of the Ottoman Empire. Considered among the construction types that formed the Western appearance of the city at that time, $19^{\text {th }}$ century hotels built in this environment have changed the conventional accommodation concept and architecture of the period, playing an important role in the development process of accommodation structures. ${ }^{1}$ Prior to this, visitors of the city used to stay in small hostels operated by foreigners, rooms for singles, almshouses, embassies, churches, and guesthouses of monasteries. ${ }^{2}$

In general, the $19^{\text {th }}$ century hotels were built and operated by non-Muslim minorities. These hotels were built in Pera for various reasons like the foreigners preference to stay close to embassies and to have a view of Golden Horn and also the government did not want the foreigners to stay in Istanbul. ${ }^{3}$

At the beginning of the $19^{\text {th }}$ century, most people who lodged in hotels were visiting the country for official duty or for business and trade. However as of the second half of the century, visits for touristic purposes started as well. One of the most important reasons underlying this was the more secure environment provided to foreigners and the improvements in the transportation system.

In 1883, "La Compagnie Internationale des Wagon-Lits" started operating "Orient Express", which began its journey in Paris, stopping at various cities in Europe and reaching all the way to Istanbul after a 14-hour steamship that departs from Varna. The direct train service from Paris to Istanbul did not start until 1889 and the service continued until $1977 .^{4}$

"Wagon Lits" Company opened its first agency in Istanbul in 1894. ${ }^{5}$ Tourists who came to Istanbul with Orient Express used to stay in Grand Hotel de Luxembourg and Hotel Angleterre. Afterwards "Wagon Lits" started to manage its own hotels in order to provide better accommodation means to their passengers, the company had Bosphorus Summer Palas and Prinkipo Palas built and also acquired Pera Palace

\footnotetext{
Kayın, 2001, pp. 19.

Cezar, 1994, pp. 398-400.

Cezar, 1994, pp. 398-400.
}

\footnotetext{
4 Demiroğlu, 2006, pp. 44-45.

5 Akçura, 2002, pp. 112.
}

Hotel from their owners and put the hotel into service. ${ }^{6} \mathrm{~A}$ lot of famous Turkish statesmen like Ismet Inönü, Celal Bayar, Adnan Menderes, Fahri Korutürk and foreign statesman like Zog I King of Albania, Mohammed Reza Pahlavi Shah of Iran, Edward VIII King of the United Kingdom, King Ferdinand of Bulgaria, Tito President of Yugoslavia; writers and artists like Pierre Loti, Lord Kinross, Alfred Hitchcock, Ernest Hemingway, Greta Garbo, Sarah Bernhardt, Agahta Christie, Julio Iglesias; spies like Mata-Hari, Cicero lodged in this hotel. Room number 101 on the first floor where Atatürk stayed was turned into a museum in 1981 . $^{7}$

\section{History and Cultural Value}

In the last years of Ottoman Empire, the city had become more dynamic in terms of international tourism as Istanbul turned its face to the West, welcoming its social and economic impacts and a railway system connecting the city to major cities in Europe was built, and eventually this lead to a need for hotels with higher comfort levels.

Three Armenian capitalists (Ohannes Kiyorkof, Artin Manokyan ve Arslanoğlu Manok), observing these physical changes and the lack of a luxurious hotel purchased the land of the hotel in $1879 .{ }^{8}$ The construction of the hotel was started in 1893 and completed in 1894. Opening ceremony was held in the first months of 1895, during the time Sultan Abdulhamit II governed the Ottoman Empire. At that time, the hotel used to give service only to men and women were not allowed to enter the hotel even if their husband accompanied them. The most significant privilege of the hotel was the availability of electricity. The Sultan who was afraid of assassination by way of electricity and electrical wires installed, permitted only a few places to have electricity and Pera Palace Hotel was one of them. ${ }^{9}$

In 1896, hotel was transferred to "Compagnie Internationale des Grands Hotels" founded by "Wagon Lits" just for the purpose of hotel management business. And the hotel started offering service to passengers of "Orient Express".

In "Le Moniteur Ottoman" newspaper's 4 December 1893 issue, it is stated that the hotel was designed by Levantine architects Alexandre Vallaury and Henri Duray, born in Istanbul. Furthermore it is announced on the same issue that "Wagon Lits" has leased the hotel for 25 years. The hotel's name was referred to as "Pera Palace" for the first time in the 1985 issue of LMO. ${ }^{10}$

Adversely affected by the First World War, "Wagon Lits" transferred the management of the hotel to Anastassiadis Family in 1915 and finally in 1923 the ownership of the hotel was transferred to the treasury due to the debts of the family. ${ }^{11}$ After the ownership of the hotel has changed nu-
Zat, 2005, pp. 65-66.

Deleon, 1993, pp. 38-41.

8 Gülersoy, 1994, pp. 230-240.
9 Ka-Ba, 2007.

${ }^{10}$ Çilli, 2009.

${ }^{11}$ Gülersoy, 1994, pp. 239-240. 


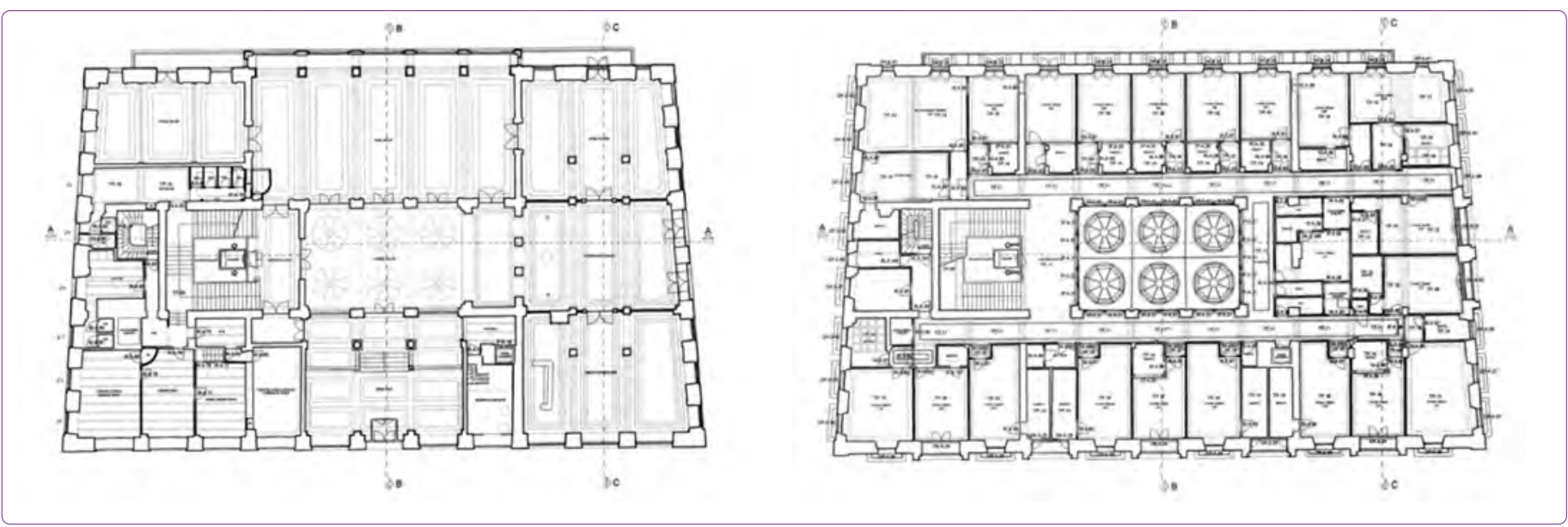

Figure 1. Ground floor and $2^{\text {th }}$ floor plans.

merous times until 1994, the hotel was finally transferred to Ministry of Culture.

\section{Architectural Description}

The structure set on a rectangle floor of $46 \times 28$ meters has nine floors with two floors of basement. Being built on a sloping terrain, the building has different number of floors above ground, the eastern and northern façade has 7 floors, and western façade has 9 floors above ground while the southern façade has 8 floors above ground. The hotel has 146 rooms with 26 rooms on the penthouse floor. Ground floor with the entrance, lobby, reception, café, bar room, ballroom and restaurants is a communal area. Basement floors are reserved for service and technical installations. The six floors cover the rooms and suits, circulation spaces and service venues (Fig. 1). A wooden cage style elevator with a wide marble staircase and decorated iron partitions connects the ground floor to the rooms.

The structure was tempered in different periods. On the northern façade, a concrete patio was added in front of the basement floors in 1972 to function as a parking lot and water tank. In 1987, in order to add rooms to the penthouse, the original roof was elevated and its form was modified. Also according to the layout, depending on requirements for use, changes were made in some spaces without modifying the structural system (adding bathrooms to the guest rooms etc....).

\section{Plan}

Plan is organized around the lighted courtyard formed in the center where triple axis system intersects. In the left axis of this area used as "ballroom" on the ground floor,
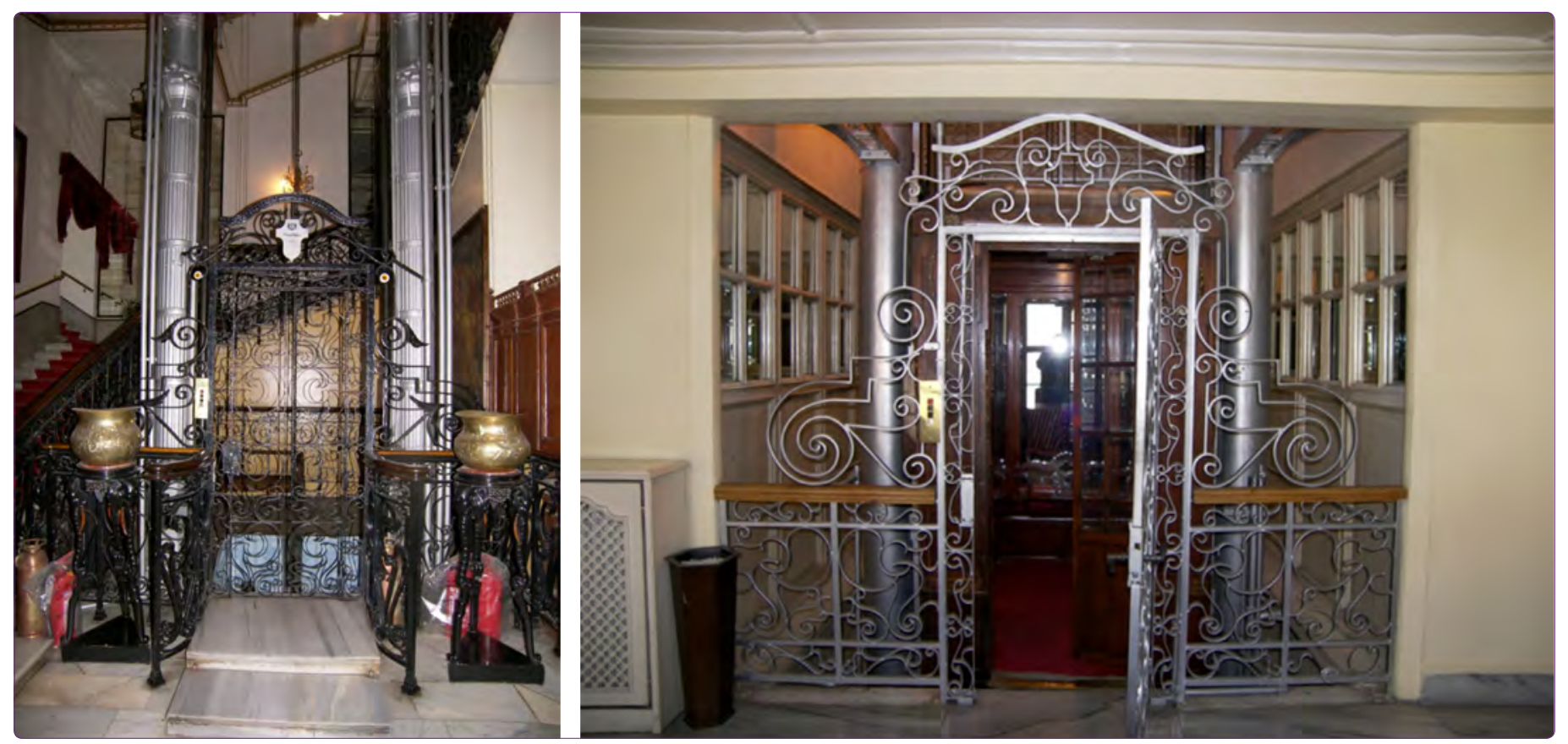

Figure 2. Art nouveau elevator. 

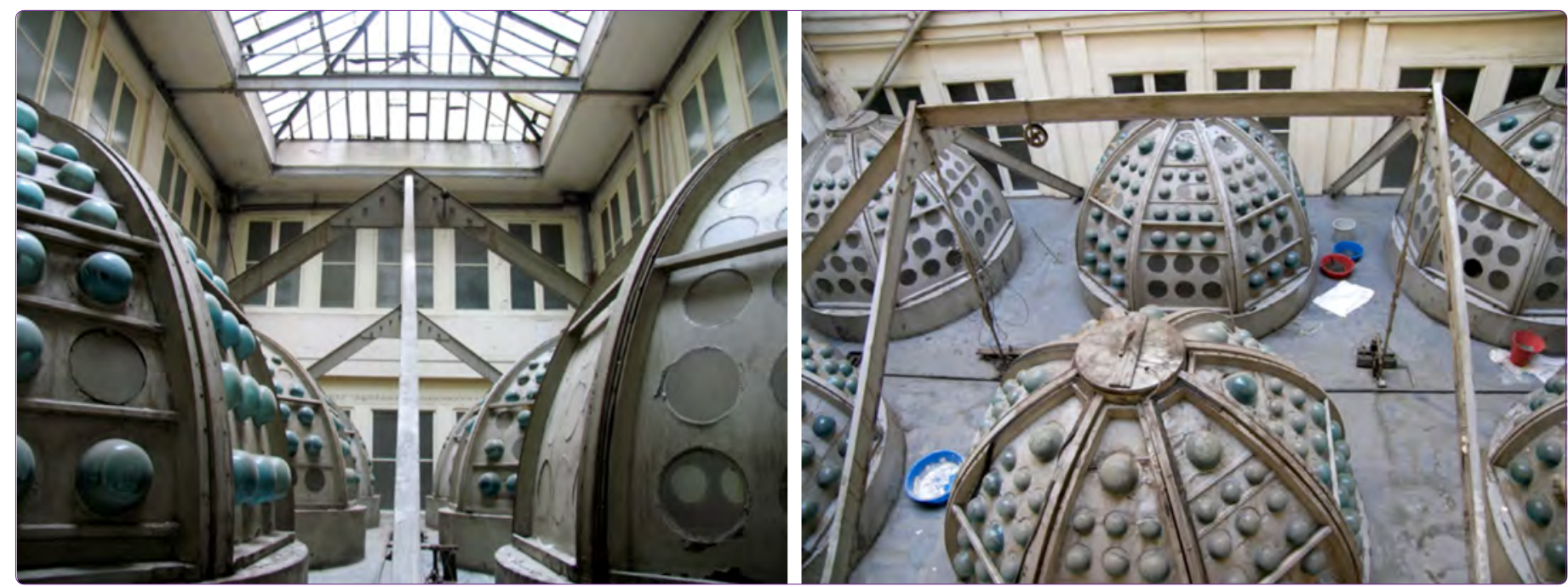

Figure 3. The ceiling of the ballroom.

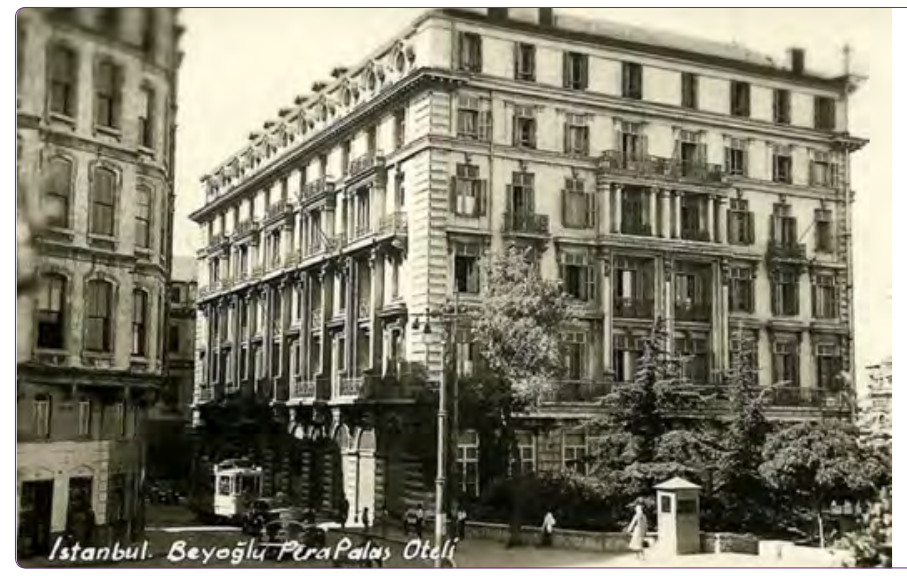

Figure 4. View from the northeast and entrance (east) façade drawing.

there is an Art Nouveau elevator made of cast iron and steel and a wide stairs surrounding it, which can be considered as a pioneer of that period (Fig. 2).

The entrance of the hotel is through a wide lobby on the south façade. Along the west façade of the ground floor, there are the dining halls opening to Golden Horn. Orientalist style was used in the two-floor ballroom with flat arches decorated with items engraved from two color marbles and pillars painted with stucco technique. The ceiling of the hall made in the form of an inner court is covered with six small domes coated with turquoise colored glasses (Fig. 3).

On two sides of the central space the aisles stretch out opening to the bedrooms on the top floors. On the first three floors, bedrooms lay along on only one side of the aisles however on the upper floors, bedrooms lay along both sides of the aisle (Fig. 1).

\section{Façades}

Pera Palace Hotel is a typical example of Istanbul architecture of the end of $19^{\text {th }}$ century. On the elevations a neoclassical approach was implemented. The building is a single large block with the corners set with straight cut stones from the floor up to the roof. Façades are divided into four with moldings on ground floor, third and fourth floor and their layouts are different from one another. All façades are organized symmetrically in respect of the central axis (Fig. 4).

Entrance façade on the east starts with pillars covered with straight cut stones and a series of marble arches. The entrance eave of the building is from an iron-structure wide marquee covered with glasses. Between the pilasters continuing to $1^{\text {st }}$ and $2^{\text {nd }}$ floor, open and closed balconies are built alternately, with cast iron guardrails. On the $3^{\text {rd }}$ floor, alternately rooms have balconies framed with double İonic columns. On the $5^{\text {th }}$ floor, the façade ends with round-formed windows having slates in between.

Due to the slope, on the west façade, $1^{\text {st }}$ and $2^{\text {nd }}$ basement floors can be seen. There is a projection along the length of 5 window apertures between the long balconies on the ground floor supported by dual consoles. At this 


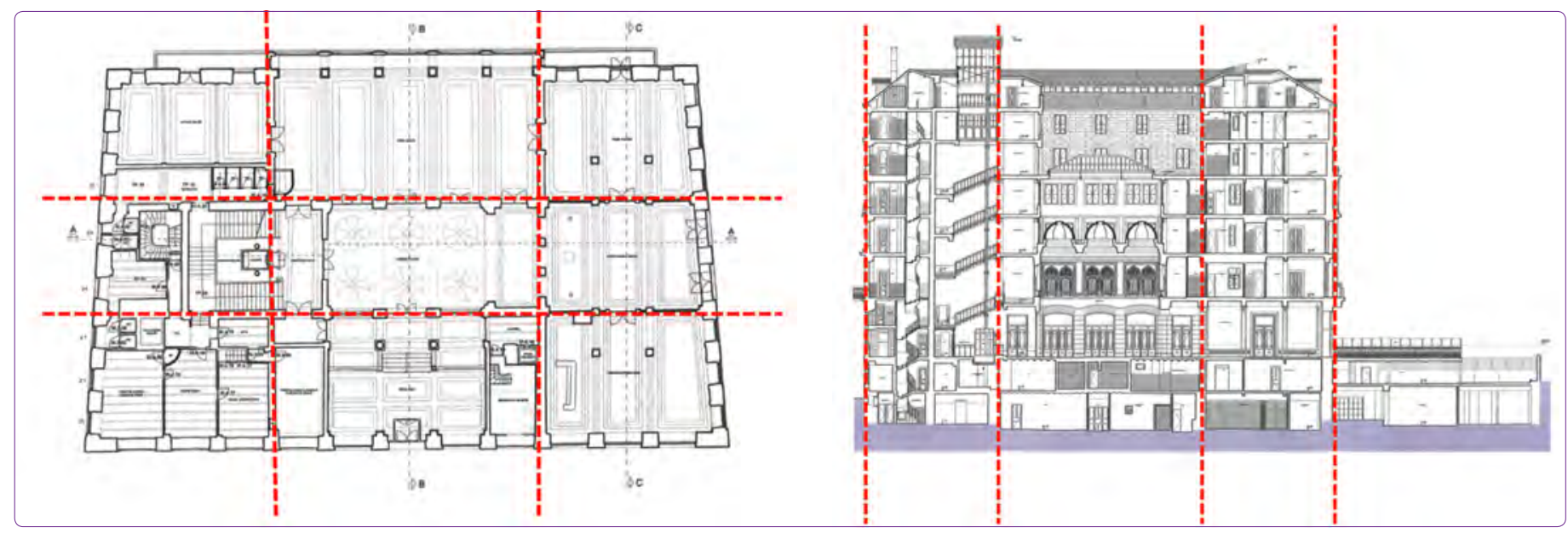

Figure 5. Structural axes on ground floor and longitudinal section.
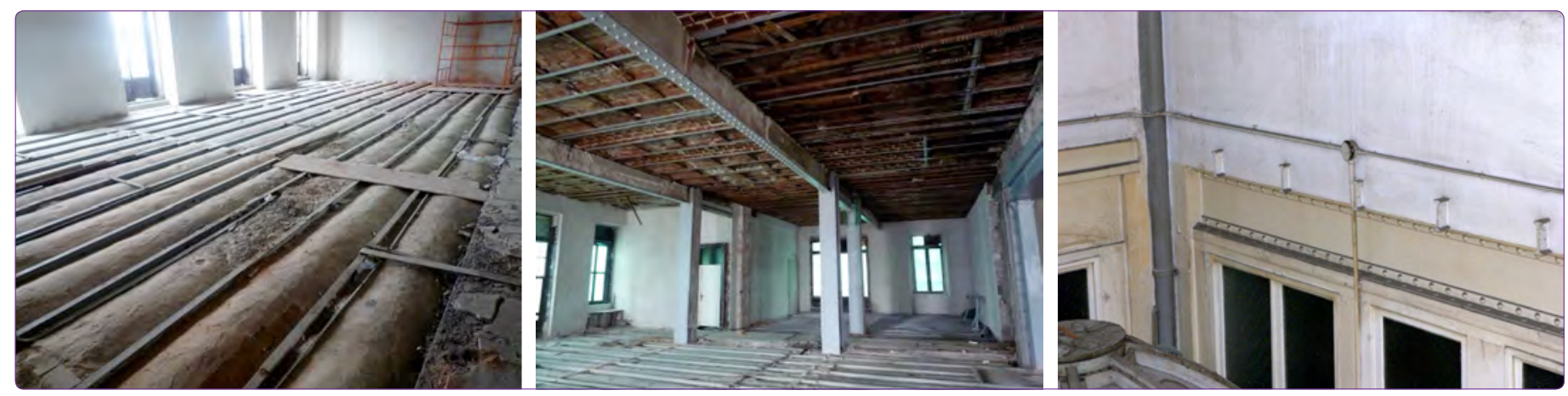

Figure 6. Arched floor system of Pera Palace Hotel.

level, cut stone imitation plaster is applied. Unlike other façades, balconies are available along this façade with the view of Golden Horn.

On the Northern façade, balconies have a symmetric layout. Following the same order, high pilasters and ionic pillars are formed at the center of the façade. The Southern fa-çade is designed with a similar setup, more plain compared to the others.

\section{Construction System and Materials}

Overall the structure, limestone coating is used on all façades. Only the Eastern façade is covered with marble up to the moldings under the balconies on the $1^{\text {st }}$ floor. Cornices, window frames, pilasters, braces, copings along the edges of the balconies and straight cut stones on the corners of the structure are all made of limestone. Plaster bind-ing agent used for the structure is lime with hydraulic properties and sand is used as aggregate. Banisters on balconies and window frames are made of wood; eaves on the en-trance façade, guardrails on balconies and window grids are made of iron. ${ }^{12}$

The floor-framing plan of the structure is organized as a three axis both transversally and longitudinally. Con-

\footnotetext{
${ }^{12}$ Ka-Ba, 2007.
}

struction system of the structure is composed of masonryarched floor, masonry walls of brick and steel beams and columns. Partition walls are made up of a brick ( $5 \mathrm{~cm}$ thick) (Fig. 5).

Initiated with the usage of European fabricated bricks as vertical carriers; changes in the process of construction technology in Ottoman architecture have continued with the us-age of timber, the most suitable material for meeting tensile and compressive forces, as horizontal carriers. Parallel to the development of industrial metal technology in European countries, "steel girders" have started to be used within the field of building production technology with the evolution of steel manufacturing since the mid$19^{\text {th }}$ century. Within this period of time, while vertical carriers were composed with fabricated bricks in masonry techniques, horizontal carriers were mostly built with a special technology named as "arched floor system" (voute française) (Fig. 6). Hence, completely resistant structures were started to be produced against fires, which constitutes one of the major problems for Istanbul until that period of time because of the timber usage in buildings.

One of the first structures built with the above-mentioned construction technology of Ottoman architecture is Pera Palace Hotel. In the hotel, at the connections of 

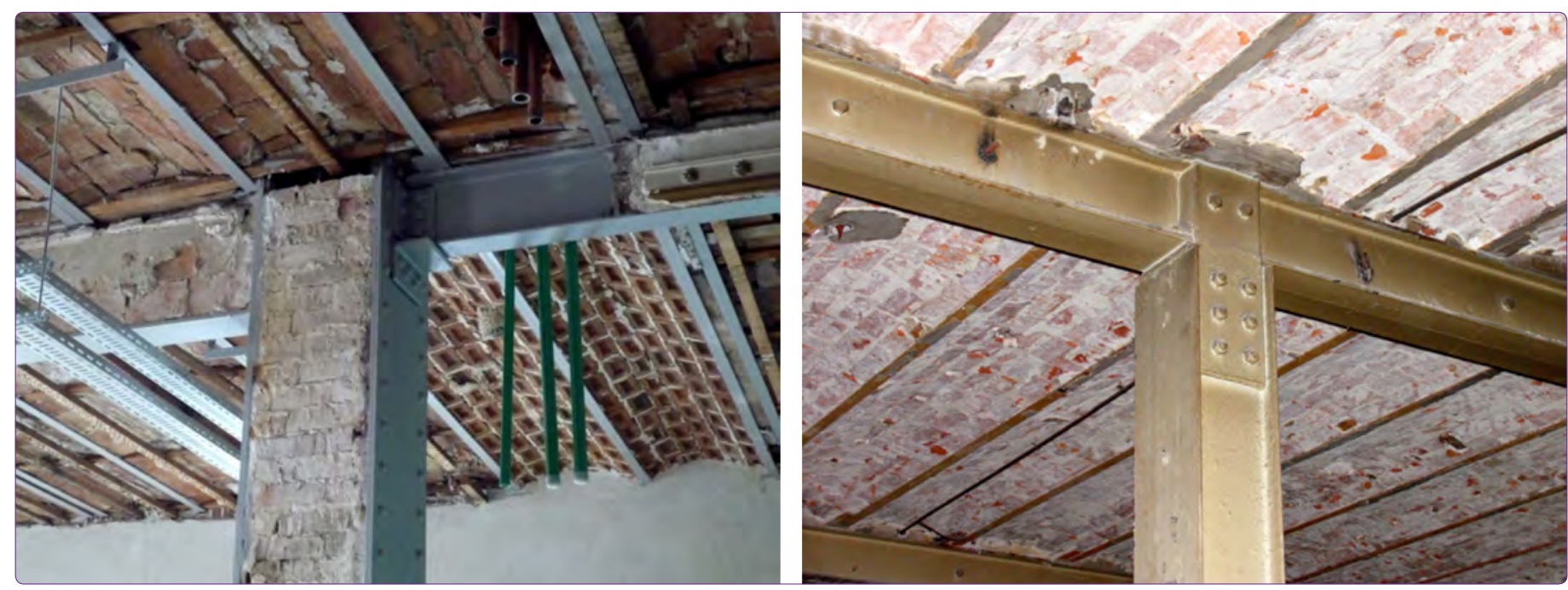

Figure 7. Structure system of Pera Palace Hotel.

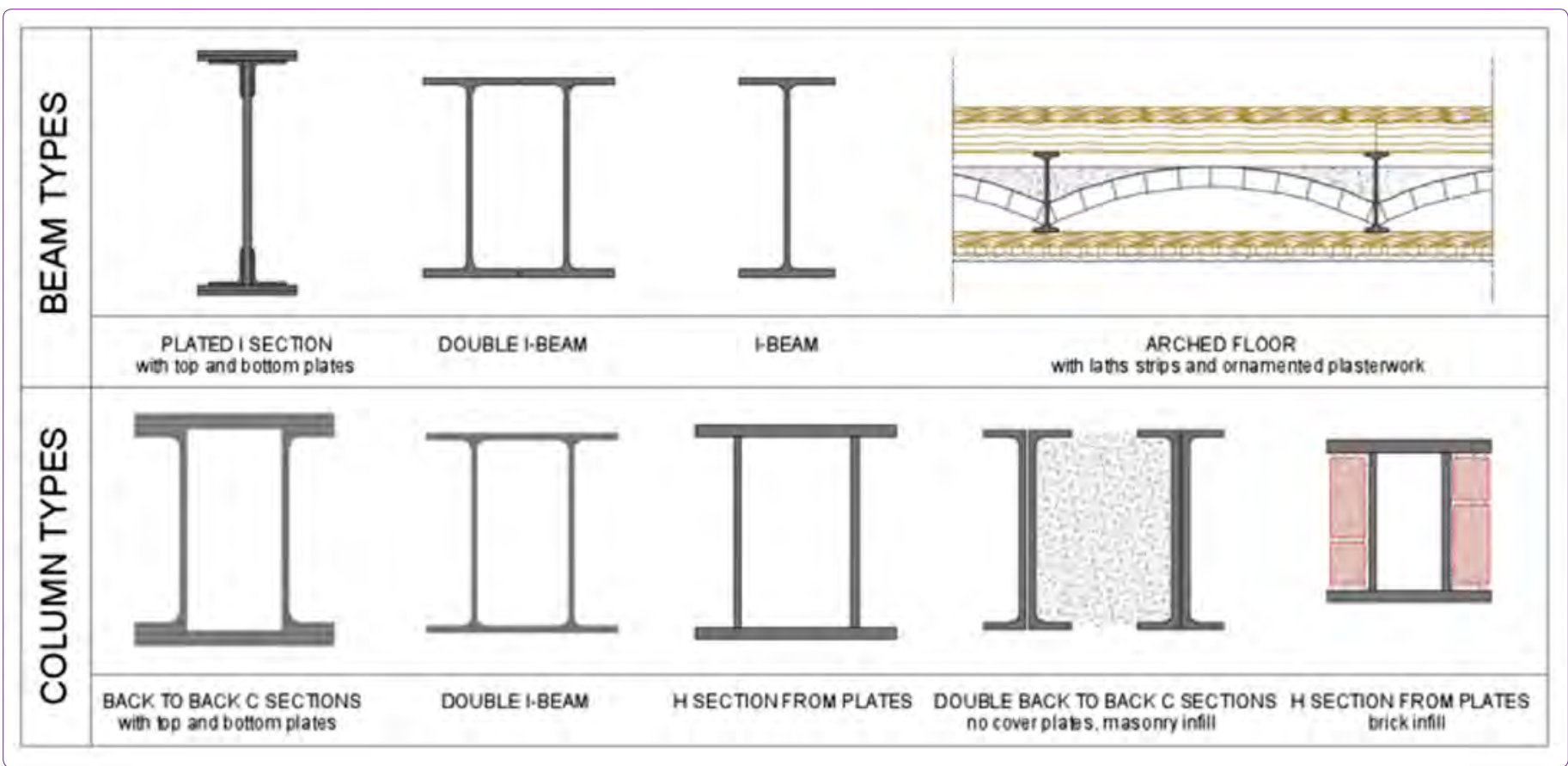

Figure 8. Column and beam types of the structure used in Pera Palace Hotel.

exterior walls and beams, I-beam is placed inside the masonry wall of brick with iron tie-rod and anchor plate (Fig. 7). The steel girders forming the structure frame of the building are used at different shapes and sizes depending on the space. In some cases 2 steel chan-nels are forming back to back $C$ sections with top and bottom plates and in other columns, 1,5 rows of brick are placed between 2 steel channels as built up box section or $\mathrm{H}$ section from plates were placed. For the beams, 2 steel channels forming back-to-back C-section, I-beam or I section with top and bottom plates are used (Fig. 8).

Ceiling of the ballroom at the center of the building is divided in three parts with rec-tangular wooden beams.
Each part has two domes covered with turquoise colored glasses. Each dome is divided into eight with wooden ribs starting from the top of vault. These domes allow sunlight to enter into this self-enclosed space (Fig 3). The ceilings of the other spaces of the building are covered with pine laths and ornamented plaster-work.

\section{Conclusions}

With a history of more than a century, Pera Palace Hotel, located on the hills of Beyoglu district, looking over the Golden Horn reflects the architectural and technical features of its period in a quiet unique way. The civil cultural asset registered in 1972, as "the first steel skeleton struc- 
tural influenced by Western eclectisism", did not undergo a critical conservation and restoration until 2014.

The building is a typical example of Istanbul architecture in the end of $19^{\text {th }}$ century. A Neoclassical approach can be seen in the plan and façade of the building, with Orientalist features predominating the interior decoration along with art nouveau and Art Deco touches. Technologically and in terms of its structural, electrical and mechanical features, a much more superior technique is used in the building compared to the innovative buildings. At that period, the building has brought many innovations in regards to construction technology and hotel management services.

The building, generally defined as museum-hotel, follows a sustainability approach and renders services to guests who wish to stay in the guest rooms and benefit from all facilities of the hotel, along with allowing visitors who wish to see the hotel for its historical-cultural heritage and use its other facilities besides accommodation (restaurant, bar, health club etc. ...).

Owing to its historical and cultural significance, more than being just a simple city hotel, Pera Palace Hotel is considered as a very important cultural asset that managed to maintain its original function and character from the day of its establishment until today.

\section{References}

Akçura, G. (2002) Turizm Yıl Sıfir, İstanbul, Om Press.

Cezar, M. (1994) 19. Yüzyılda Beyoğlu Neden ve Nasıl Gelişti, Ankara, Türk Ta-rih Kurumu Press.

Çilli, Ö. (2009) “Tanzimat Sonrası Osmanlı Otel Mimarisi Ve Pera Palas", Un-published Master Thesis, Institut of Social Sciences of Hacettepe University.

Deleon, J. (1993) Pera Palas, İstanbul, İstanbul Otelcilik ve Turizm Ticaret A.Ş.

Demiroğlu, C. (2006) Kültürel Miras ve Turizmle Ilişkisi Bağlamında Prinkipo Palace (Büyükada Rum Yetimhanesi) Uygulanabilir Bir Yatırım Projesi Önerisi, İstanbul.

Gülersoy, Ç. (1994) “Pera Palas”, Encyclopedia of Dünden Bugüne Istanbul, Is-tanbul, Türkiye Ekonomik ve Toplumsal Tarih Vakfi Press.

Ka-Ba (2007) Pera Palas - Istanbul Koruma, Onarım, Sağlıklaştrrma Ve Ye-nileme Projesi, Ankara.

Kayın, E. (2001) İzmir Oteller Tarihi, İzmir, İzmir Büyükşehir Belediyesi Kent Kitaplığı.

Zat, V. (2005) Eski Istanbul Otelleri, Istanbul, Bilge Karınca Press, pp 65-66. 